\title{
Being elderly with functional dependence and their family caregivers
}

\author{
Ser idoso com incapacidade e seus cuidadores familiares \\ Ser anciano con incapacidady sus cuidadores familiares
}

Amanda Maria Souza de Oliveira ${ }^{1}$, Larissa Chaves Pedreira ${ }^{2}$

\begin{abstract}
Objective: To identify the authors ` point of discussion on the elderly with functional dependence, correlating it with the ontological time discussed in Heidegger. Methods: This is a bibliographic, systematic and qualitative study. Data was collected in the Scientific Electronic Library Online database. A total of 123 studies were identified, 15 studies were included considering the inclusion criteria. Results: Based on the semantic analysis of Bardin, the following categories of analysis were established: being caregiver for the elderly with functional dependence, being elderly with functional dependence, family dynamics. Conclusion: It was understood that factors related to the worldliness of these people as family relationships, support of formal and informal services, economic and social situation, among others, are part of the history of these people influencing their modes of being. Searching to understand these factors is important to promote the health of these people, thinking of the biological and existential care.
\end{abstract}

Keywords: Aged; Disabled health; Philosophy, nursing; Review literature as topic; Caregivers

\section{RESUMO}

Objetivo: Identificar o ponto de discussão dos autores sobre o idoso com incapacidade funcional, correlacionando com o tempo ontológico heideggeriano. Métodos: Estudo do tipo bibliográfico, sistemático e qualitativo. Os dados foram coletados no banco de dados do Scientific Electronic Library Online. Do total de 123 publicações identificadas, foram selecionados 15 estudos, conforme os critérios de inclusão adotados. Resultados: Com base na análise temática de Bardin, foram constituídas as seguintes categorias de análise: ser-cuidador do idoso com incapacidade, ser-idoso com incapacidade, dinâmica familiar. Conclusão: Compreendeu-se que fatores relacionados à mundanidade dessas pessoas como relação familiar, apoio dos serviços formais e informais, situação econômica, social, entre outras, fazem parte da historicidade destas influenciando seus modos de ser. Buscar a compreensão desses fatores é importante para promover a saúde dessas pessoas, pensando nos cuidados biológicos e existenciais. Descritores: Idoso; Saúde da pessoa com deficiência; Filosofia em enfermagem; Literatura de revisão como assunto; Cuidadores

\section{RESUMEN}

Objetivo: Identificar el punto de discusión de los autores sobre el anciano con incapacidad funcional, correlacionando con el tiempo ontológico heideggeriano. Métodos: Estudio de tipo bibliográfico, sistemático y cualitativo. Los datos fueron recolectados en el banco de datos del Scientific Electronic Library Online. De un total de 123 publicaciones identificadas, fueron seleccionados 15 estudios, de acuerdo a los criterios de inclusión adoptados. Resultados: Con base en el análisis temático de Bardin, fueron constituídas las siguientes categorías de análisis: ser-cuidador del anciano con incapacidad, ser-anciano con incapacidad, dinámica familiar. Conclusión: Se comprendió que los factores relacionados a a relación familiar, apoyo de los servicios formales e informales, situación económica, social, entre otras, forman parte de la historicidad de éstas influenciando su modo de ser. Es importante buscar la comprensión de estos factores para promover la salud de estas personas, pensando en los cuidados biológicos y existenciales.

Descriptores: Anciano; Salud de la persona con discapacidad; Filosofía en enfermería; Literatura de revisión como asunto; Cuidadores

\footnotetext{
${ }^{1}$ Graduate student (Masters). Graduate Program, Federal University of Babia-UFBA, Salvador, Babia, Brazil

${ }^{2}$ Adjunct Professor. Federal University of Babia - UFBA, Salvador, Babia, Brazil
} 


\section{INTRODUCTION}

The impact of having someone in the family with functional dependence is massive and deserves special attention from health care programs.

In 2008, the Ministry of Health published the Practical Guide for Family Caregivers ${ }^{(1)}$, which provides guidance on the care that must be provided to the elderly, how to act in emergency situations, rights and well-being of the caregiver, as well as the maintenance and rehabilitation of elderly functional dependence. The same guide defines caregivers as "a person of the family or community, who provides care to another person of any age who is in need of care by being bedridden with physical or mental limitations, with or without income."

Functional dependence is the inability to perform activities of daily living. In the elderly, this can lead to health problems, depression, isolation and dependency, therefore rehabilitation and family support is important to facilitate the return to daily activities, and the recovery of autonomy, which is essential to their quality of life. But there are barriers in maintaining this autonomy, such as lack of physical structure inside and outside the home and overprotective family members who often treats them as incapable, leaving the elderly in an awkward and limitation situation, stopping them from performing tasks which they can still perform.

Among the diseases that most affect and incapacitate the elderly population, diseases of the circulatory system ranks first in the proportion of hospitalizations of elderly in the Unified Health System, in Bahia and Salvador ${ }^{(2)}$. In this context, cerebrovascular accident (CVA) is referred to as the main cause of functional dependence in elderly people from the Western Hemisphere $^{(3)}$. Those who have suffered episodes of stroke are six times more likely to develop some sort of dependency than those without the disease ${ }^{(4)}$. Thus, the presence of a caregiver becomes necessary to assist in their activities of daily living, which may be performed by a professional or a family member.

Functional and cognitive disabilities, mostly caused by CVA, have changed the life of many elderly and their families, leading them to difficulties in family relationships. This modification in the existence of these people, in addition to their life contexts, experiences, opportunities, among others, leads them to present different modes of being.

The elderly person with some functional dependence and his/her caregiver may present various modes of being, depending on their openness to the world, as a mode of being that presents itself now, will not be equal to the one that comes after ${ }^{(5)}$. These modes of being depend on how each person interacts with the world, which is considered all things and people around the person. Heidegger calls this between man and the things of the world Worldliness or Worldhood of the world.

In this sense, considering the Heideggerian philosophical time as the horizon where the being happens, is related to everyday life, in which we can see the presence of modes of being.

Thus, the present research aimed to identify the authors 'point of discussion on the elderly with functional dependence, correlating with the ontological time discussed in Heidegger.

\section{METHODS}

This is a bibliographical, systematic and qualitative study, linked to the Research Line: The Caring in Nursing in the Process of Human Development, from the Study Group of Nursing Care, Federal University of Bahia (UFBA).

This type of research aims to use as a data source the literature on a particular subject, seeking to systematize it in order to provide a summary of evidence related to the strategies of action. Such studies are important to select information about a particular topic, raise conflicting or coincident points, identify possible gaps and serve as a basis for future investigations ${ }^{(6)}$.

This study was extracted from an undergraduate research project of UFBA, funded by CNPq, which aimed to identify the state of the art with respect to ontological time and the elderly people experience with functional dependence correlating it to the ontological time discussed in Heidegger.

The project was characterized as a quantitative and qualitative research, with data collection in Theses Database of Coordination of Improvement of Higher Education Personnel (CAPES) and the Database of Scientific Electronic Library Online, considering its scientific relevance given the significant number of national and international journals indexed to them, allowing the expanded thematic and satisfactory range to the type of research. We considered texts from all countries linked to the Databases, in Portuguese, English and Spanish.

The search was performed using the keywords: functional independence or dependence, elderly and cerebrovascular accident, philosophy and its synonyms, resulting in 123 publications, including articles, theses and dissertations. After that, inclusion criteria were applied: the abstract or key words present at least two of the chosen keywords; be written in English, Portuguese or Spanish; have a clear methodology in the abstract; and refer to the elderly population.

For the present study, of qualitative approach, the correlation between Heideggerian ontological time and elderly with functional dependence was applied, which occurred in the discussion via full texts referring to 
Heidegger time, and as exclusion criteria: articles which presented an incomplete abstract, with quantitative methodology and did not have the full text available. Two authors independently analyzed the texts.

The bibliographic search occurred between August and November of 2008. With reading of the material, units of analysis were constituted, following the semantic analysis of Bardin, with one or more semantic categories and units of meaning in a predetermined coding unit ${ }^{(7)}$. The correlation between Heideggerian ontological time and elderly with functional dependence has been discussed in the texts referring to Heidegger`s time.

\section{RESULTS}

We selected 15 studies that met the inclusion/ exclusion criteria (Table 1). None with the keyword philosophy or their synonyms were found. No CAPES papers were selected due to the lack of availability to full text.

Table 1. Summary of selected researches for study

\begin{tabular}{|c|c|c|c|c|c|}
\hline Title & Author (s) & $\begin{array}{l}\text { Year } \\
\text { (Country) }\end{array}$ & Objective & Study design & Outcome \\
\hline $\begin{array}{l}\text { Caring for the } \\
\text { highly dependent } \\
\text { elderly in the } \\
\text { community: a study } \\
\text { on the main family } \\
\text { caregivers }\end{array}$ & $\begin{array}{l}\text { Silveira TM, } \\
\text { Caldas CP, } \\
\text { Carneiro } \\
\text { TF }^{(10)}\end{array}$ & $\begin{array}{l}2006 \\
\text { (Brazil) }\end{array}$ & $\begin{array}{l}\text { To contribute for a better } \\
\text { understanding of family } \\
\text { main caregivers of highly } \\
\text { dependent elderly }\end{array}$ & $\begin{array}{l}\text { Cross-sectional } \\
\text { study using a } \\
\text { qualitative method } \\
\text { for content analysis }\end{array}$ & $\begin{array}{l}\text { Influence the relationship } \\
\text { caregiver/elderly: } \\
\text { multigenerational transmission, } \\
\text { elderly participation in the } \\
\text { decision of a caregivers, support } \\
\text { group for family members }\end{array}$ \\
\hline $\begin{array}{l}\text { Dependent seniors: } \\
\text { families and } \\
\text { caregivers. }\end{array}$ & $\begin{array}{l}\text { Karsch } \\
\mathrm{UM}^{(11)}\end{array}$ & $\begin{array}{l}2003 \\
\text { (Brazil) }\end{array}$ & Opinion Article & Opinion Article & $\begin{array}{l}\text { Delegate the care function to } \\
\text { the family needs clarity about } \\
\text { family structure, type of care } \\
\text { and disease and professional } \\
\text { monitoring. }\end{array}$ \\
\hline $\begin{array}{l}\text { Katz index on } \\
\text { elderly functionality } \\
\text { evaluation }\end{array}$ & $\begin{array}{l}\text { Duarte } \\
\text { YAO, } \\
\text { Andrade } \\
\text { CL, Lebrão } \\
\text { ML }^{(12)}\end{array}$ & $\begin{array}{l}2007 \\
\text { (Brazil) }\end{array}$ & $\begin{array}{l}\text { To rescue the historical } \\
\text { development, evolution } \\
\text { and use of the Index of } \\
\text { Independence in Activities } \\
\text { of Daily Living in order to } \\
\text { standardize their use }\end{array}$ & Bibliographic search & $\begin{array}{l}\text { The Katz Index, throughout its } \\
\text { history, has undergone changes } \\
\text { after tests but it still has } \\
\text { limitations in its application. }\end{array}$ \\
\hline $\begin{array}{l}\text { FavoAging with } \\
\text { dependence:family } \\
\text { needs and } \\
\text { responsibilities }\end{array}$ & $\begin{array}{l}\text { Caldas } \\
\mathrm{CP}^{(13)}\end{array}$ & $\begin{array}{l}2003 \\
\text { (Brazil) }\end{array}$ & $\begin{array}{l}\text { Point the aging } \\
\text { phenomenon with } \\
\text { dependence as a challenge } \\
\text { to be incorporated by Public } \\
\text { Health and discuss the } \\
\text { responsibility for assisting } \\
\text { this population }\end{array}$ & $\begin{array}{l}\text { Critical revision } \\
\text { grounded in } \\
\text { theoretical and } \\
\text { conceptual content }\end{array}$ & $\begin{array}{l}\text { The dependency must be } \\
\text { addressed through programs } \\
\text { that include strategies from } \\
\text { health promotion, to the } \\
\text { establishment of support } \\
\text { networks to long-term care in } \\
\text { the community }\end{array}$ \\
\hline $\begin{array}{l}\text { Cerebrovascular } \\
\text { accident in the } \\
\text { aged: changes In } \\
\text { family relations }\end{array}$ & $\begin{array}{l}\text { Marques S, } \\
\text { Rodrigues } \\
\text { RAP, } \\
\text { Kusumota } \\
\text { L }^{(17)}\end{array}$ & $\begin{array}{l}2006 \\
\text { (Brazil) }\end{array}$ & $\begin{array}{l}\text { To identify elderly, at the } \\
\text { Emergency Unit with a CVA } \\
\text { diagnosis, and their families, } \\
\text { and to identify changes in } \\
\text { family relations, after the event. }\end{array}$ & $\begin{array}{l}\text { Qualitative study } \\
\text { using the Critical } \\
\text { Incident Technique. }\end{array}$ & $\begin{array}{l}\text { Need to work with family, } \\
\text { identifying changes and } \\
\text { developing an action plan } \\
\text { that fosters relationships and } \\
\text { adaptations of the family. }\end{array}$ \\
\hline $\begin{array}{l}\text { It changed } \\
\text { everything! The } \\
\text { impact of the } \\
\text { stroke on the family }\end{array}$ & $\begin{array}{l}\text { Brito ES, } \\
\text { Rabinovich } \\
\text { EP (24) }\end{array}$ & $\begin{array}{l}2008 \\
\text { (Brazil) }\end{array}$ & $\begin{array}{l}\text { To investigate families of } \\
\text { CVA patients, including } \\
\text { socioeconomic and } \\
\text { emotional difficulties, } \\
\text { the relationship between } \\
\text { severity of injury, time of } \\
\text { occurrence and development } \\
\text { of care strategies. }\end{array}$ & $\begin{array}{l}\text { Qualitative study } \\
\text { using Technical } \\
\text { Analysis of } \\
\text { Discourse of the } \\
\text { Collective Subject. }\end{array}$ & $\begin{array}{l}\text { The family goes through a } \\
\text { transformation process that } \\
\text { involves reorganization and } \\
\text { adoption of coping strategies } \\
\text { favored by the existence of a } \\
\text { support network. }\end{array}$ \\
\hline $\begin{array}{l}\text { Meeting at home: } \\
\text { a proposal of } \\
\text { home attendance } \\
\text { for families of } \\
\text { dependent seniors. }\end{array}$ & $\begin{array}{l}\text { Silva L, } \\
\text { Galera SAF, } \\
\text { Moreno } \\
\mathrm{V}^{(25)}\end{array}$ & $\begin{array}{l}2007 \\
\text { (Brazil) }\end{array}$ & $\begin{array}{l}\text { To describe how the } \\
\text { family system reacts to the } \\
\text { situation of an elderly with } \\
\text { functional dependence, } \\
\text { which resources are used to } \\
\text { maintain the stability and } \\
\text { nursing care in this context. }\end{array}$ & $\begin{array}{l}\text { Qualitative study } \\
\text { using as a theoretical } \\
\text { framework the } \\
\text { family systems } \\
\text { approach in systemic } \\
\text { reference }\end{array}$ & $\begin{array}{l}\text { Nursing has much to } \\
\text { contribute in assisting families } \\
\text { and may contribute to } \\
\text { improving the living conditions } \\
\text { of the family group. }\end{array}$ \\
\hline $\begin{array}{l}\text { The Bambuí } \\
\text { Health and Aging } \\
\text { Study (BHAS):the } \\
\text { experience with } \\
\text { home care provided } \\
\text { by wives of } \\
\text { dependent elderly }\end{array}$ & $\begin{array}{l}\text { Giacomin } \\
\text { KC, } \\
\text { Uchoa E, } \\
\text { Lima-Costa } \\
\text { MFF }^{(9)}\end{array}$ & $\begin{array}{l}2005 \\
\text { (Brazil) }\end{array}$ & $\begin{array}{l}\text { To investigate the } \\
\text { characteristics of the caring } \\
\text { process and the experience } \\
\text { of women who care for } \\
\text { their elderly husbands in } \\
\text { Bambuí. }\end{array}$ & $\begin{array}{l}\text { Qualitative study of } \\
\text { population-based } \\
\text { cohort }\end{array}$ & $\begin{array}{l}\text { Caregivers and people who } \\
\text { need care lives the harsh reality } \\
\text { of functional dependence, } \\
\text { integrally, intuitively and } \\
\text { improvised. }\end{array}$ \\
\hline
\end{tabular}




\begin{tabular}{|c|c|c|c|c|c|}
\hline Title & Author (s) & $\begin{array}{l}\text { Year } \\
\text { (Country) }\end{array}$ & Objective & Study design & Outcome \\
\hline $\begin{array}{l}\text { Interaction between } \\
\text { stroke survivorsand } \\
\text { family caregivers: } \\
\text { shared autonomy }\end{array}$ & $\begin{array}{l}\text { Bocchi } \\
\text { SCM, } \\
\text { Angelo } \\
M^{(27)}\end{array}$ & $\begin{array}{l}2005 \\
\text { (Brazil) }\end{array}$ & $\begin{array}{l}\text { To understand the } \\
\text { experience of family } \\
\text { caregivers of people with } \\
\text { CVA, on the modalities } \\
\text { of care taken during } \\
\text { rehabilitation at home. }\end{array}$ & $\begin{array}{l}\text { A qualitative study, } \\
\text { using Grounded } \\
\text { Theory as its } \\
\text { methodology. }\end{array}$ & $\begin{array}{l}\text { The family caregiver realizes } \\
\text { that the process of recovery } \\
\text { of individual autonomy and } \\
\text { its own interdependent and } \\
\text { contingent on rehabilitation } \\
\text { achieved by the patient. }\end{array}$ \\
\hline $\begin{array}{l}\text { Subjective well } \\
\text { being and perceived } \\
\text { psychological } \\
\text { adjustment among } \\
\text { old people affected } \\
\text { by stroke: a review }\end{array}$ & $\begin{array}{l}\text { Rabelo DF, } \\
\text { Néri AL }{ }^{(31)}\end{array}$ & $\begin{array}{l}2006 \\
\text { (Brazil) }\end{array}$ & $\begin{array}{l}\text { to identify variables that } \\
\text { mediate the relationship } \\
\text { between the sense of } \\
\text { psychological adjustment } \\
\text { and CVA in the elderly. }\end{array}$ & Bibliographic search & $\begin{array}{l}\text { Variables that may worsen } \\
\text { the psychological well-being: } \\
\text { functional dependence, } \\
\text { cognitive deficits, and restricted } \\
\text { activities }\end{array}$ \\
\hline $\begin{array}{l}\text { The family also } \\
\text { becomes sick! } \\
\text { Changes secondary } \\
\text { to stroke occurring } \\
\text { within families }\end{array}$ & $\begin{array}{l}\text { Brito ES, } \\
\text { Rabinovich } \\
\text { EP }^{(28)}\end{array}$ & $\begin{array}{l}2008 \\
\text { (Brazil) }\end{array}$ & $\begin{array}{l}\text { To Understand the impact } \\
\text { of disabling illnesses, and } \\
\text { the strategies used by the } \\
\text { family in the performance } \\
\text { of duties of care for people } \\
\text { with physical disabilities } \\
\text { after a CVA. }\end{array}$ & $\begin{array}{l}\text { Qualitative study } \\
\text { using Technical } \\
\text { Analysis of } \\
\text { Discourse. Of the } \\
\text { Collective Subject }\end{array}$ & $\begin{array}{l}\text { The occurrence of a CVA is an } \\
\text { experience marked by changes } \\
\text { in daily family life and the lives } \\
\text { of its members. There is a need } \\
\text { to enable the family to care and } \\
\text { self-care. }\end{array}$ \\
\hline $\begin{array}{l}\text { Living the burden } \\
\text { in becoming a } \\
\text { family caregiver for } \\
\text { a cerebrovascular } \\
\text { accident survivor: } \\
\text { knowledge analysis }\end{array}$ & Bocchi SCM & $\begin{array}{l}2004 \\
\text { (Brazil) }\end{array}$ & $\begin{array}{l}\text { To make a semantic } \\
\text { analysis of the production } \\
\text { of knowledge, about the } \\
\text { burden placed on family } \\
\text { caregivers of people with } \\
\text { CVA. }\end{array}$ & $\begin{array}{l}\text { Bibliographic } \\
\text { Research }\end{array}$ & $\begin{array}{l}\text { The degree of disability } \\
\text { determines the need for } \\
\text { assistance, and a challenge to } \\
\text { the family who experiences } \\
\text { changes in their lifestyle. }\end{array}$ \\
\hline $\begin{array}{l}\text { Psychological } \\
\text { resources and } \\
\text { personalAdjustment } \\
\text { for functional } \\
\text { incapacity in aging }\end{array}$ & $\begin{array}{l}\text { Rabelo DF, } \\
\text { Néri AL }{ }^{(27)}\end{array}$ & $\begin{array}{l}2005 \\
\text { (Brazil) }\end{array}$ & $\begin{array}{l}\text { To present how individuals } \\
\text { face losses in physical } \\
\text { functions and social roles, } \\
\text { and the extent to which the } \\
\text { social and pschicological } \\
\text { resources act on chronic } \\
\text { conditions on quality of life } \\
\text { for the elderly. }\end{array}$ & $\begin{array}{l}\text { Bibliographic } \\
\text { Review }\end{array}$ & $\begin{array}{l}\text { The availability of } \\
\text { psychological and social } \\
\text { resources are important as } \\
\text { social support, beliefs and } \\
\text { positive emotional states, } \\
\text { affective regulation, and the } \\
\text { sense of self-perceived efficacy. }\end{array}$ \\
\hline $\begin{array}{l}\text { The existential } \\
\text { dimensions of the } \\
\text { elderly and their } \\
\text { caregivers }\end{array}$ & $\begin{array}{l}\text { Caldas } \\
\mathrm{CP}^{(30)}\end{array}$ & $\begin{array}{l}2000 \\
\text { (Brazil) }\end{array}$ & $\begin{array}{l}\text { Discuss the question } \\
\text { "elderly care" in } \\
\text { phenomenological view }\end{array}$ & $\begin{array}{l}\text { Reflection on the } \\
\text { contribution of } \\
\text { phenomenology to } \\
\text { elder care, valuing } \\
\text { the caregiver. }\end{array}$ & $\begin{array}{l}\text { Understanding the meaning } \\
\text { of being a caregiver will } \\
\text { contribute to nursing practice, } \\
\text { as they may be more effective } \\
\text { with caregivers. }\end{array}$ \\
\hline
\end{tabular}

In identifying the ideas raised by the authors, the following semantics categories were found: deficiency of formal support for the elderly and family, performance of activities of daily living and instrumental activities of daily living, family dynamics, coping with functional dependent elderly, caregivers and elderly profiles with functional dependence who, together, formed the units of analysis: being the caregiver of elderly with functional dependence; being elderly with functional dependence; and family dynamics.

\section{DISCUSSION}

\section{Being the caregiver of elderly with functional dependence}

Authors show that the profile of the caregiver is usually women ${ }^{(8,9)}$. This caregiver definition follows patterns, myths and beliefs characterized by each family system, which defines not only its appearance, but also the role of each member in the family ${ }^{(10)}$.
In most cases, these women are elderly, and mostly consisted of wives, followed by daughters, with low income and education. They take responsibility for caring with little or no help from other family members, in an improvised and solitary manner as an unquestionable obligation because they are wives for all times. Furthermore, following a cultural determination that care is something that is connected to women ${ }^{(8,9)}$.

Consequently, taking care is an imposition of the circumstances, it is not an option, a thought act or something which is jointly decided. In most cases, the person perceives himself/herself forced to take care due to the unwillingness of others. Unfortunately, the need to reduce costs of hospital and institutional care to elderly with dependency has led many countries, such as Brazil, to indicate that these people should stay at home, without any formal support ${ }^{(11)}$.

Aging with dependency and the emergence of a caregiver require new forms of assistance and Public Policy approaches that guide care to this population. 
The problem of a functional dependent elderly cannot be solved with their care relying only on the family, who is often funded by the elderly retirement, therefore, the difficulty in providing such care is notorious ${ }^{(12)}$. Families become increasingly nuclear and face changes in the roles of its members, hindering their participation in taking care of the elderly and leading to lack of care for the most dependent ones ${ }^{(13-26)}$.

Thus, not only the elderly is harmed regarding their lack of care, as there is a family overload. A study showed that caregivers spend at least 3 hours daily caring ${ }^{(14,26)}$. Moreover, their daily lives are divided between care for the elderly and household chores, work, children care, among others ${ }^{(15,26)}$.

Concerning this question, studies show that in many cases the need to care for a family member at home, led many families, especially women, to quit their jobs or they were made redundant ${ }^{(11,16)}$. In addition, most families survive with little, and having to bear costs of medications, food, rental equipment, among others ${ }^{(17)}$.

In this context, caregivers, based on their life or job experiences, experience this care in a very special way. The way they deal with this concern, relate to this elderly and their needs, depends on how they perceive and respond to the demands around them.

In this sense, the human being is an entity able to comprehend the being of being, whose essence is the existence. His only way to prove it is through his modes of being expressed in a specific time and space ${ }^{(18)}$. For Heidegger, time is the unfinished, the transcendental horizon where the being appears, saving relationship with everyday life, in which we see the manifestations of being ${ }^{(19)}$.

At the beginning and in most cases we have multiple modes of being, which depend on various ways how the world touches us, depending on a previous state of mood also called spiritual state ${ }^{(20)}$.

In the caregivers, this previous state of spirit will always be related to the difficulties or easiness of everyday care: help from formal and informal system of care, economic situation, other obligations, leisure possibilities, among others ${ }^{(29)}$.

\section{Being Elderly with functional dependence}

If for the family the routine of care of a functional dependent elderly is hard, for him, being dependent is also not easy. Although one study ${ }^{(21)}$ has demonstrated a reduction in the number of elderly with dependency between 1998 and 2003, justifying the result by improving the health of the population, the number of elderly with dependency is still high, considering the aging process, their losses and chronic degenerative diseases with its consequences, among them, the stroke (CVA).
A study on functional dependence in the elderly in Latin America and the Caribbean shows that Brazil has the largest number of elderly with cognitive impairment, with the worst educational level and with the highest level of depression. Regarding the frequency of dependency and non-communicable diseases in the elderly, the country has the largest number of people with difficulties in activities of daily living and instrumental activities of daily living, and the frequency of stroke, Brazil is in second place ${ }^{(22)}$.

So, being dependent, even partially, is a challenge that causes different responses depending on a number of factors such as: experiences, worldviews, individuals characteristics, access and quality of formal and informal network support, among others.

Rabelo and Neri, report that the most influential factors in the recovery and psychological adjustment of older people with functional dependence are social and rehabilitation support programs, informal support, higher education, good cognitive ability, the continuation of a productive occupation, maintenance of instrumental activities of daily living and positive $\operatorname{mood}^{(31)}$.

Regarding the importance of education and material circumstances in the process of adaptation to dependency of the elderly, a study shows that these are the dominant factors of the different responses of women to the dependency ${ }^{(21)}$. Thus, the more integrated psychologically and socially better adjusted the elderly with dependency will feel, thus reducing the burden for family, caregivers and health services.

Another point raised by Marques et al is that home care or other health care environments exacerbate the feeling of helplessness, "paralyzing" the person, limiting their possibilities of controlling over themselves and what is around. That is when the loss of autonomy emerges in the cared subject ${ }^{(17)}$.

Also in this sense, there is a trend towards a reduction in outside activities for elderly people with functional dependence. This leads to a progressive reduction of external contacts and in the circle of relationships, leading to a decrease in social network support, greater elderly dependency on others and the increased family burden ${ }^{(12)}$.

So the elderly with some dependency being cared at home can show up through various modes of being, as occupation, as indifference, as aggressivity, as passivity, among others, depending on their openness to the world, the way they receive the demands of the world and the answers of each time.

Often the elderly with functional dependency, is in a state of mood that nullifies possibilities, throwing himself into a routine in which everything is already given, apparently without prospects for changes. Often, the possibilities of these elderly are already given, 
usually by the family. So, the autonomy of the other is taken, imposing them to what is convenient.

\section{Family dynamics}

A study that sought to identify changes in family relationships after CVA found that most families, despite survive with little, is destructured, but the harmony and understanding among its members can rearrange this family system ${ }^{(17)}$.

Marques et al emphasize the importance of interpersonal relationships among family members, through communication and mutual understanding. This situation, imposed by the provision of care for the elderly, provides elderly and caregivers an opportunity to gain a new perspective on themselves and others, as well as new opportunities to approach the family ${ }^{(17)}$.

Nevertheless, some families cannot harmonize their relationship, worsening relations with verbal offense and rejection of care, among others. These cases may be linked to the experience of these people and their relationship: elderly and their families, before the event that caused dependency.

Regarding this aspect, it is pointed the importance of strengthening relations between the cared individual, their families and health professionals, surpassing these authoritarian and paternalistic relationships, and working to expand the autonomy, as the therapeutic process advances ${ }^{(23)}$.

The emergence of CVA disorganizes the family, requiring rapid adoption of coping strategies. Among the sensitive moments are: the occurrence of the event, hospitalization and the arrival of the patient at home ${ }^{(28)}$.

Thus, the family reacts using welcoming and care strategies, although they are not prepared to develop such tasks. The confrontation is favored by the existence of an effective support network in the supply of physical, social, financial and emotional demands, and its importance is related to the severity of the deficit presented by him/her.

Changes in the routine of family life when the onset of a disease, destabilizes its stability, when myths, beliefs and patterns are questioned ${ }^{(10)}$. Therefore, it is important to understand that being and time walk along each other, one cannot try to understand the being, through their modes of being, without considering their temporality, marked by worldliness of each one. People react to their world demands in a very particular way, so each individual has his/her temporality.

Along with this same line of thought, a research on elderly families with functional dependency shows how thinking in the context of caregivers and the elderly is important for understanding the modes of being of these people, in order to plan appropriate interventions ${ }^{(25)}$.

It is necessary that the health staff in their daily care routine, try to seek and to understand the modes of being of others, based on their worldliness, surpassing logical thinking, and trying to get to the essence of what is shown. Therefore, there is need to implement education programs addressed to families and caregivers of people with functional dependence, in order to prepare them for coping with chronic diseases.

Furthermore, it is important to struggle for investments in formal training and qualification of people for informal support to this population, this is one way to improve the elderly authonomy, reducing the burden on caregivers and family conflicts.

\section{CONCLUSION}

Functional dependence and CVA are issues which are still little addressed, but growing, following the increased interest in this population by researchers.

No studies were found relating to temporality, although many studies have addressed conflicts between the elderly and their caregivers. It is important to think of time in these studies because population aging brings social demands, which can be best understood by looking for other fields of knowledge.

The study showed the need for investments in formal and informal support to give assistance to this population; this is one way to lessen the burden on caregivers and family conflicts. Besides the importance of the healthcare team to see the cared being based on his/her temporality, trying to overcome the logical thinking, seeing beyond what is shown.

Finally, we must be alert to mediate these relationships, paying attention to factors that may improve the wellbeing at home and it is important that nurses and other professionals pay attention to it in home visits, during qualification and monitoring of caregivers. 


\section{REFERENCES}

1. Brasil. Ministério da Saúde. Secretaria da Gestão do Trabalho e da Educação. Guia prático do cuidador. Brasília(DF): Ministério da Saúde; 2008.

2. Brasil. Ministério da Saúde. Indicadores de morbidade e fatores de risco [Internet] [citado 2009 Mar 8]. Disponível em: http://tabnet.datasus.gov.br/cgi/tabcgi.exe?idb2007/ d13.def.

3. André C. Manual de AVC. Rio de Janeiro: Revinter; 1999.

4. Rosa TE, Benício MH, Latorre MR, Ramos LR. [Determinant factors of functional status among the elderly]. Rev Saúde Pública. 2009;37(1): 40-8. Portuguese.

5. Pedreira LC. Modos de ser do idoso com sequela de acidente vascular cerebral: cuidado familiar [tese]. Salvador: Universidade Federal da Bahia, Escola de Enfermagem; 2009.

6. Sampaio RF, Mancini MC. Systematic review studies: a guide for careful synthesis of the scientific evidence. Rev Bras Fisioter. 2007;11(1):77-82.

7. Bardin L. Análise de conteúdo. Lisboa: Edições; 2009.

8. Luzardo AM, Gorini MI, Silva AP. [Characteristics of elderly with Alzheimer's disease and their caregivers: a series of cases in a neurogeriatric service]. Texto \& Contexto Enferm. 2006; 15(4): 587- 94. Portuguese.

9. Giacomin KC, Uchoa E, Lima-Costa MF. [The Bambuí Health and Aging Study (BHAS): the experience with home care provided by wives of dependent elderly]. Cad Saúde Pública. 2005;21(5): 1509 -18. Portuguese.

10. Silveira TM, Caldas CP, Carneiro TF.[Caring for the highly dependent elderly in the community: a study on the main family caregivers]. Cad Saúde Pública .2006;22(8):1629-38. Portuguese.

11. Karsch UM. [Dependent seniors: families and caregivers]. Cad Saúde Pública. 2003; 19(3): 861-6. Portuguese.

12. Duarte YA, Andrade CL, Lebrao ML. [Katz Index on elderly functionality evaluation]. Rev Esc Enferm USP. 2007; 41(2): 317-25. Portuguese.

13. Caldas CP. [Aging with dependence: family needs and responsibilities]. Cad Saúde Pública. 2003; 19(3): 733-81. Portuguese.

14. Gonçalves LH, Alvarez AM, Sena EL, Santana LW, Vicente FR. [Profile of the family caregiver for frail/sick elderly in the sociocultural context of Florianópolis, SC]. Texto \& Contexto Enferm. 2006; 5(4):570-7. Portuguese.

15. Ocampo JM, Herrera JA, Torres P, Rodríguez JA, Lisboa L, Garcia CA. [Caregiver burden in dependent elderly]. Colomb Med. 2007; 38(1):40-6. Portuguese.
16. Garrido R, Menezes PR. [Impact on caregivers of elderly patients with dementia treated at a psychogeriatric service]. Rev Saúde Pública. 2004;38(6): 835-41. Portuguese.

17. Marques S, Rodrigues RA, Kusumota L. Cerebrovascular accident in the aged: changes in family relations. Rev Latinoam Enferm. 2006;14(3): 364-71.

18. Heidegger M. Ser e Tempo. Parte I. Cavalcante MS, tradutor. Petrópolis: Vozes; 1998.

19. Ferreira AM. A finitude do tempo em Heidegger. In: Salles JC. Filosofia e consciência social [Internet]. Salvador: Quarteto; 2003 [citado 2012 Jan 10]. Disponível em: http:/ / dc307.4shared.com/doc/KLcEbPWh/preview.html

20. Inwood M. Heidegger . Trad. Abgail Ubirajara Sobral. São Paulo: Loyola; 2000. (Coleção Mestres do Pensar)

21. Parahyba MI, Veras R, Melzer D. Disability among elderly women in Brazil. Rev Saúde Pública. 2005; 39(3): 383-91.

22. Menéndez J, Guevara A, Arcia N, León Diaz EM, Marin C, Alfonso JC. [Chronic diseases and functional limitation in older adults: a comparative study in seven cities of Latin America and the Caribbean]. Rev Panam Salud Publica. 2005;17(5-6): 353-61. Spanish.

23. Soares JC, Camargo Junior KR. Patient autonomy in the therapeutic process as a value for health. Interface (Botucatu). 2007; 11(21): 65-78.

24. Brito ES, Rabinovich EP. [It changed everything! The impact of the stroke on the family]. Saude Soc . 2008;17(2):153-69. Portuguese.

25. Silva L, Galera SA, Moreno V. Meeting at home: a proposal of home attendance for families of dependent seniors. Acta Paul Enferm. 2007;20(4): 397-403.

26. Fernandes MGM, Garcia TR. [Determinatives of the tension of the dependent elderly's family caregiver]. Rev. bras. Enferm. 2009; 62(3): 393-399. Portuguese.

27. Bocchi SCM, Angelo M.[ Interaction between stroke survivors and family caregivers: shared autonomy]. Ciênc. saúde coletiva, 2005; 10(3): 729-738. Portuguese.

28. Brito ES, Rabinovich EP. [The family also becomes sick! Changes secondary to stroke occurring within families]. Interface (Botucatu) 2008; 12(27): 783-794. Portuguese.

30. Caldas CP. [The existential dimensions of the elderly and their caregivers]. Textos envelhecimento, 2000; 3(4):29-41. Portuguese.

31. Rabelo DF, Neri AL. [Subjective well being and perceived psychological adjustment among old people affected by stroke: a review]. Estud. psicol. (Natal). 2006; 11 (2):169-77. Portuguese. 